\title{
FOREIGN AND UKRAINIAN EXPERIENCE OF EMPLOYEE MOTIVATION ACCOUNTING
}

\section{ЗАРУБІЖНИЙ ТА УКРАЇНСЬКИЙ ДОСВІД ОБЛІКУ МОТИВАЦІЇ ПРАЦІВНИКІВ}

UDC 657.471 .12

https://doi.org/10.32843/infrastruct37-110

\section{Rozit Tatiana}

Candidate of Economic Sciences,

Associate Professor,

Senior Lecturer at Department

of Statistics, Accounting and Audit

V.N. Karazin Kharkiv National University

Travkina Karyna

Student

V.N. Karazin Kharkiv National University
The article discusses the main existing types of motivation incentives for employees. Both material and non-material incentives were highlighted among them. The incentive system for workers in countries such as the United States of America, Japan and some countries of the European Union is described. The relationship between cultural values of the inhabitants of these countries and their preferred types of encouragement is considered. And the most desirable types of intangible incentives among employees of the American companies are also studied. It is noted that the creation of an effective incentive system involves not only the payment of bonus remuneration, but also contributes to the interest of employees in the results of their work and significantly encourages them to participate in the development of the enterprise. The difference between the concepts of "stimulating payments" and "labor stimulation" is given. The IAS 19 "Employee Benefits" is considered and compared with Ukrainian standards. The necessity for Ukraine to adopt foreign experience to solve the existing difficulties is justified.

Key words: employee benefit accounting, perks, perquisites, bonus award, incentives.

В cmamье рассмотрены основные суще ствующие виды мотивирующих поощрений для работников. Среди которых были выде- лены как материальные, так и нематериальные. Описана система стимулирования работников в таких странах, как Соединенные Штаты Америки, Япония и некоторые страны Европейского Союза. Рассмотрена связь между культурными ценностями жителями данных стран и предпочти тельными ими видами поошрения. А также изучены наиболее желаемые виды нематериальных поощрений среди работников американских компаний. Отмечено, что создание эффрективной системы поощрения, предполагает не только выплату премиальных вознаграждений, но и способствует заинтересованности работников в резульmaтах своего труда и в значительной мере побуждает их участвовать в процессе развития предприятия. Приведенная разница между понятиями «стимулирующие выплаты» и «стимулирование труда». Рассмотрен международный стандарт финансовой отчетности IAS 19 «Вознаграждения работникам» и сравнен с украинскими стандартами. Обоснована необходимость для Украины в перенимании зарубежного опыта для решения имеющихся трудностей. Ключевые слова: учет вознаграждений работникам, надбавки, льготы, премии, поощрения.

У статті розглянуті основні існуючі види мотивуючих заохочень для працівників. Серед яких були виділені як матеріальні, так і нематеріальні. Досліджене українське законодавство, а також література вказали на те, що премія є частиною заробітної плати. Описана система стимулювання працівників в таких країнах, як Сполучені Штати Америки, Японія і деякі країни Європейського Союзу. Виявлено що в цих країнах найбільш розповсюдженими є нематеріальне стимулювання. Розглянуто зв'язок між культурними цінностями жителями цих країн і переважними ними видами заохочення. Виявлено, що для країн з британо-американьскої моделлю обліку найбажанішим заохоченням є оплата навчання та підвищення кваліфрікації робітника. Також вивчені найбільш бажані види нематеріальних заохочень серед працівників великих американських компаній. В той час як в країнах з континентальною моделлю обліку на перше місце постає такий «бенефіт» як отримання чеків на придбання товарів в магазинах-партнерах, а матеріальне стимулювання є звичним лише два рази на рік перед Різдвом та наприкіниі весни, для того щоб робітник міг дозволити собі літню відпустку. Японія хоча і входить до континентальної моделі обліку, але тут є чітка відмінність у бажаних заохоченнях. Так на перше місце для робітників Японії постає піклування про здоров'я, але при цьому не фрізичне, а духовне. Відзначено, що створення ефективної системи заохочення, передбачає не тільки виплату преміальних винагород, а й сприяє зацікавленості працівників у результатах своєї праці і в значній мірі спонукає їх брати участь в процесі розвитку підприємства. Наведена різничя між поняттями «стимулюючі виплати» $i$ «стимулювання праці». Розглянуто міжнародний стандарт фрінансової звітності IAS 19 «Виплати працівникам» та порівняний з українськими стандартами. Обірунтовано необхідність для України перейняття закордонного досвіду для вирішення наявних труднощів. Головною проблемою в цьому питанні для України залишається низький рівень заробітних плат, що робить матеріальне заохочення більш ціннішим для робітників, в той час як увесь світ признав, що на перше місце необхідно виводити нематеріальне стимулювання, оскільки саме воно несе найбільшу двосторонню вигоду, як роботодавцю так і робітнику.

Ключові слова: облік винагород працівникам, надбавки, пільги, премії, заохочення.

Problem statement. In modern conditions of development of Ukrainian society, it is very important not to lose labor force in the country and to be able to properly stimulate workers to work in our own enterprises. It should be noted that the stimulation can be both material and by providing various non-monetary benefits for workers. The second type is widely applicable in Europe, the USA and Japan. But along with this, the question of choosing an accounting model of labor stimulation costs arises, because intangible incentives are much different from the monetary form of incentives. For accounting in Ukraine, this issue is still quite unexplored.

Analysis of recent research and publications. The classics such as A. Smith, F. Gilbret, A. Maslow,
F. Herzberg, A. Afonin, R. Owen, D. McGregor, V. Vrum and others have made significant contributions to the development of issues related to the motivation of work. There can be distinguished the researchers in Ukraine, such as: Mashkov K. E. [1], Kovalenko O. O. [2], Kovalenko S. V. [2]. Also the research of Robert Klonoski [3], an American scientist, was considered.

Formulation of the problem. The purpose of the article is to highlight foreign experience of intangible incentive and the practice of accounting, considering the possibilities of borrowing experience for Ukrainian workers.

Research statement. Today, in addition to the usual cash bonuses (material incentives), such forms 
of rewards as a package of additional free rewards are gaining popularity. But such a practice is widely used only abroad, and in Ukrainian realities the material incentives dominate, the practice of non-material incentives is used mainly in large companies.

Having examined the Ukrainian legislation, it should be noted that according to Article 97 of the Labor Code of Ukraine, commercial organizations determine the amount of wages to employees independently. The specific sizes of tariff rates and piecerates for workers, official salaries of employees, as well as allowances, surcharges, bonuses and remuneration are established by the owner or his authorized body, taking into account the requirements provided in part two of this article [4].

Accordingly, the question of the relationship between cash bonus and wages arises. K. Mashkov makes arguments and concludes that the bonus is part of the salary, since it is part of its structure (namely, additional salary and other incentive and compensation payments), but is not included in the basic salary [1, p. 114]. This thesis means that material bonuses can be an additional reward for labor in excess of established norms, but the question of stimulating labor remains open.

The studied legislation also indicates that a huge drawback is the lack of a definition of the concepts of "incentive payments" and "labor stimulation" in the legislative framework. Very often this leads to the fact that in practice the idea of the place of incentive payments in the organization among employees and employers often does not coincide. It is imperative to understand the difference between these concepts. Under the incentive of workers refers to measures that are aimed at increasing the profits of the organization by increasing the efficiency and quality of workers. While the concept of "material incentives for employees" follows from the need to increase the profits of the organization. Therefore, directly on the basis of the profit received, it is possible to form material incentive funds for workers. Consequently, the concept of "stimulation" is not limited only to the material factor, but includes other forms of encouragement.

Ukrainian legislation also does not provide a clear list of incentive payments. They can be established exclusively in the collective agreement or internal regulatory document of the organization. But, based on the situation, their design requires detailed study in order to justify it, since this is connected with tax risks, very often this moment remains fully unlit. Today, the most common types of incentives for employees include: bonuses, medical insurance, social benefits (payment of meals, training, utilities, rental housing), financial assistance for the main vacation, payment for mobile communications.

Returning to foreign experience, international standards should be considered. So, the main standard that defines the procedure for accounting for employee benefits is IAS 19 "Employee Benefits" [5], while it complements an entirely different standard - IAS 26 "Accounting and Reporting by Retirement Benefit Plans" [6]. In accordance with IAS 19 the employee benefits are all forms of compensation that the company provides employees in exchange for the services they provide or termination of the employment agreement. Unlike Ukrainian standards, IAS 19 demonstrates the separation of 4 types of pay obligations. There are short-term, long-term, post-employment and termination benefits (fig. 1).

Short-term employee benefits according to IAS 19 are divided into groups: wages, salaries, social security contribution; short-term paid leave; profit sharing and/or bonuses; non-monetary benefits. Short-term employee benefits according IAS 19 are recognized as a liability with a simultaneous accrual of expenses. At the same time, the following entries are made in accounting:

1) recognition in accounting of labor costs:

Debit "Personnel costs (labor remuneration)"

Credit "Liabilities for Employee compensation";

2) payment of employee benefits:

Debit "Liabilities for Employee compensation"

Credit "Cash".

The United States refers to countries with a British-American accounting model, which means that the payment of various training courses and the education of a worker are considered to be desirable intangible incentives for workers to work in the USA. It can be language courses, driver's education or even getting a master's degree in a chosen specialty. The professional growth of the employee is highly appreciated not only by the employer, but also by the worker himself. By far, the highest level of employee incentive is the provision of the possibility of owning, albeit a small, but still a share of shares. But for this type of incentive, an employee must meet a number of criteria, for example, the service life of an enterprise is more than 20 years. According to an American analytical research [7], the respondents were top managers of large companies, the desired "benefits" include full health insurance not only for the worker, but also for his family (56\%) and full payment of the worker's vacation (44\%). Robert Klonoski approves that "Benefits" are offered to employees because they promote job satisfaction and increase organizational commitment [3, p. 53].

EU countries have a continental accounting system. An unprecedented model of labor incentives is very common there; its essence is that the high level of wages performs the functions of labor incentives. So, with material payments workers in Austria have only two additional wages per year (in the winter before Christmas, and in late spring, before 


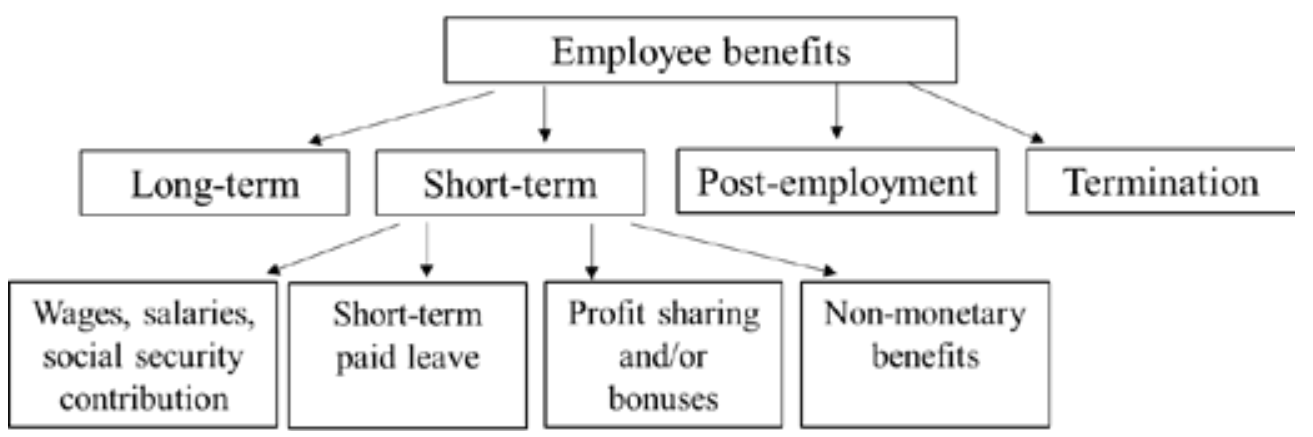

Fig. 1. Categories of employee benefits

Source: [5]

vacation). Labor efficiency of workers is stimulated by additional free payments - "Benefits". Hungarian commercial enterprises have agreements with supermarket chains, such as Spar, under the terms of which the best employees of the month have improved their labor productivity; they receive checks in the amount of 10,000-30,000 Hungarian forints which can be spent for paying goods in this particular supermarket chain.

Japan is also a country with a continental accounting model, but it uses non-standard forms of synthesis of material and non-material labor incentives in practice, ensuring the possibility to achieve a rapid industrial upsurge unknown in Europe and the USA on a qualitatively different paradigm of social development [2, p. 96]. The main advantage among intangible labor incentives in Japan is provided to support the health of the employee (physical and spiritual), not only medical insurance, but also the purchase of membership cards for sports classes, visiting psychologists.

Conclusions from the research. The Ukrainian workers have significant potential and are recognized in the world as one of the most hardworking nations. The level of wages in Ukraine is quite low, and this leads to the fact that the main form of employee labor incentives are material rewards such as bonuses. But the world has proven that intangible incentives are much more effective. It includes medical insurance, social benefits, payment for mobile communications or transport, and more. A properly formed set of "benefits" for employees will not only help in attracting the best labor force in own business, but also will give a clear understanding that the motivation of their own workers leads to an increase in the income of the enterprise.

\section{REFERENCES:}

1. Mashkov K. E. (2016) Premiyuvannya yak riznovid zaohochennya pratsivnikiv [Bonus awards as a variety of incentives for workers]. Bulletin of the Kherson State University, no. 3, pp. 113-115.

2. Kovalenko O. O., Kovalenko S. V. (2016) Dinamichna sistema individualnih pokaznikiv premiyuvannya yak suchasniy instrument motivatsiyi efektivnoyi pratsi spetsialistiv [Dynamic system of individual indicators premiuation as a modern motivation instrument effective work of specialists] Bulletin of economic science of Ukraine. no. 2, pp. 95-99.

3. Robert Klonoski (2016) Defining Employee Benefits: A Managerial Perspective International Journal of Human Resource Studies, vol. 6, no. 2, pp. 52-63

4. The Labor Code of Ukraine: Law of Ukraine. Date of Entry into Force: June 1, 1972 № 322-VIII, Available at: https://zakon.rada.gov.ua/laws/main/322-08 (accessed 10 November 2019).

5. IAS 19 Employee Benefits. Available at: https://www.ifrs.org/issued-standards/list-of-standards/ias-19-employee-benefits (accessed 16 November 2019).

6. IAS 26 Accounting and Reporting by Retirement Benefit Plans. Available at: https://www.iasplus.com/en/ standards/ias/ias26 (accessed 16 November 2019).

7. Which benefits do employees find most financially beneficial? Available at: https:// www.journalofaccountancy.com/news/2018/nov/ top-employee-benefits-201820002.html (accessed 1 November 2019). 
Rozit Tatiana

Candidate of Economic Sciences, Associate Professor, Senior Lecturer at Department of Statistics, Accounting and Audit V.N. Karazin Kharkiv National University

Travkina Karyna

Student

V.N. Karazin Kharkiv National University

\section{FOREIGN AND UKRAINIAN EXPERIENCE OF EMPLOYEE MOTIVATION ACCOUNTING}

The purpose of the article. The purpose of the article is to consider the types of employee incentives for the enterprise. As well as a detailed study of non-material incentives for workers and, having cited the experience of the USA, EU and Japan, demonstration of the importance of using this type of motivation.

Methodology. In this study, various methods are used, among which it is necessary to single out a comparative method, grouping, systematization and generalization of Internet resources. And also the article considered a very significant element of the accounting method such as double entry.

Results. The practical significance of the theoretical principles, conclusions and recommendations formulated by the author lies in the fact that they can serve as the basis for understanding the significance of non-material stimulation of workers. Also, after studying IAS 19, we identified the main types of non-financial incentives such as: bonuses, medical insurance, social benefits (payment of meals, training, utilities, rental housing), financial assistance for the main vacation, payment for mobile communications. The experience of such countries with both a continental accounting model and with the British-American is considered. It was revealed that while in the USA the payment of training and the development of employee skills is more desirable, in the EU countries the emphasis is on the personal needs of the employee. Japanese workers prefer mental and spiritual health as "benefits." The importance of non-material incentives is recognized worldwide. For Ukraine, this experience is very important. So, having overcome the low level of salaries at which the main motivation today is cash bonuses, Ukrainian companies will need to formulate the most suitable package of additional benefits that will motivate the employee to increase productivity. It will also help employers consolidate the loyalty of their most valuable employees and of course increase their profits.

Practical implications. The study revealed that a properly formed set of "benefits" for employees will not only help to attract the best workforce in their own business and increase employee loyalty, but also will give a clear understanding that the motivation of their employees leads to an increase in the income of the enterprise.

Value/originality. It consists in a theoretical generalization of the essence of intangible incentives for workers and deepening the scientific and methodological provisions of their research. The main results containing elements of scientific novelty are: apparatus for the study of motivation, the study of the relationship of employee incentives and future income of the company. Determining that the creation of an effective incentive system involves not only the payment of bonus remuneration, but also contributes to the interest of employees in the results of their work and significantly encourages them to participate in the development of the enterprise. 